\title{
WASTEWATER MANAGEMENT IN FOOD PROCESSING ENTERPRISES - A CASE STUDY OF THE CIECHANÓW DAIRY COOPERATIVE
}

\author{
Marek Gugała', Krystyna Zarzecka', Anna Sikorska' \\ 1 Siedlce University of Natural Sciences and Humanities, B. Prusa 14, 08-110 Siedlce, Poland, e-mail: gugala@ \\ uph.edu.pl; kzarzecka@uph.edu.pl
}

Received: 2014.07.20

Accepted: 2014.10.17

Published: 2015.01.02

\begin{abstract}
The paper reports on wastewater management in food processing enterprises, using the Ciechanów Dairy Cooperative as an example. The efficiency of preliminary treatment of wastewater entering the municipal sewerage system was evaluated using basic pollution indices for wastewater pre-treated in the process of chemical neutralisation as well as results of physical and chemical analyses of raw wastewater from fromage fraise and cottage cheese production lines. The number of exceedances of permissible values of pollution indices in pre-treated wastewater was determined based on values set in the water legal permits issued by the relevant authority. Pre-treated wastewater entering the municipal sewerage system met the standards for permissible wastewater pollution indicators excluding $\mathrm{BOD}_{5}$ (biochemical oxygen demand) and COD (chemical oxygen demand). Physical and chemical analysis was performed of total raw wastewater and wastewater discharged from fromage fraise and cottage cheese production lines. Pollution indicators (COD, total nitrogen, orthophosphates, total suspensions, fats, $\mathrm{pH}$ ) had high values but they remained within the ranges typical for dairy food processing.
\end{abstract}

Keywords: dairy processing wastewater, dairy processing, wastewater management, pollution indicators.

\section{INTRODUCTION}

Dairy industry is one of major branches of food processing industry in Poland. Milk production has increased by $58.9 \%$ over $2000-2010$. The yearly milk production now is almost 12 milliard litres. Assuming the indicator of wastewater volume per unit of production is $3.5 \mathrm{~m}^{3} / 1$ $\mathrm{m}^{3}$ of milk processed, it can be estimated that in Poland the daily discharge of dairy wastewater is approximately $92,000 \mathrm{~m}^{3}$ [16]. The wastewater is characterised by much higher pollution indicators and varied volumes discharged compared with municipal wastewater. As a result, it is much more difficult to exploit such dairy processing facilities [1]. Varied wastewater discharges by milk processing plants constitute an additional difficulty. Efficient treatment of dairy wastewater is of paramount importance from the standpoint of water environment protection.

\section{MATERIALS AND METHODS}

The work is based on data obtained from the Ciechanów Dairy Cooperative. The paper presents values of basic pollution indicators in wastewater treated using neutralisation. Efficiency of preliminary treatment of dairy wastewater was evaluated. Physical and chemical analyses were conducted to obtain values of basic pollution indicators in total (raw) wastewater discharged from fromage fraise and cottage cheese production lines of the Ciechanów Dairy Cooperative.

Physical and chemical analyses were conducted in 2007 at the Department of Environmental Engineering of the University of Warmia and Mazury in Olsztyn. Raw (total) wastewater as well as the wastewater discharged from fromage fraise and cottage cheese production lines were analysed. Wastewater was sampled in the morning and in the afternoon at the premises of the 
dairy processing plant. The following components were determined: total nitrogen, orthophosphates, total suspensions, fats, organic compounds and $\mathrm{pH}$. An indirect method, based on determination of the amount of oxygen used to oxidise organic compounds, was used to determine these compounds. Chemical Oxygen Demand (COD) was determined by means of the potassium dichromate method with sulphuric acid [11]. Wet mineralisation of wastewater samples was followed by determination of total nitrogen using the distillation method. The samples were filtered and used to determine spectrophotometrically the orthophosphates with the Phosver reagent (ascorbic acid) at $890 \mathrm{~nm}$. The total suspended solids were determined with the gravimetric method, whereas fats were analysed using SOXHLET extraction - a water bath was used to evaporate acidified wastewater samples, ether was removed from the extract, and the remains were dried and used to gravimetrically determine fats [11].

\section{DESCRIPTION OF WASTEWATER DISCHARGED BY MILK PROCESSING INDUSTRY}

Wastewater is one of major environmental concerns of milk processing industry. In terms of volume, dairy processing plants discharge mainly wastewater produced during washing and cleaning processes. The wastewater contains $3-4 \%$ processed milk, on average. Milk losses take place when processing begins, after periodic cleaning, when old products are replaced by new ones and when milk is spilled or leaks [3]. Dairy wastewater contains easily biodegradable organic substances. Due to rapid fermentation, resulting in a marked $\mathrm{pH}$ decrease (to $\mathrm{pH}=4.5$ ) and promoting rapid oxygen consumption, the wastewater has to be pre-treated before it is sent to drain $[16,18]$. Due to the fact that dairy processing wastewater has got much higher values of pollution indicators, compared with domestic or municipal wastewater, it is necessary to pre-treat the wastewater before it is discharged to sewers and a sewage processing plant $[1,12]$. Wastewater produced by dairy industry is a mixture of organic and inorganic sewage [8]. It also contains condensates and sewage remaining after milk cooling. The wastewater is produced at various stages and during various processes of the milk processing cycle [14]. Problems associated with pre-treatment of dairy industry wastewater arise from its specificity (it contains e.g. dissolved and crystallised fat, carbohydrates (lactose), both colloidal and clotted protein as well as cleaning-related substances) $[1,13]$.

In addition to the aforementioned proteins, carbohydrates and fats, there is a high concentration of organic nitrogen and the following ions: $\mathrm{NH}_{4}^{+}, \mathrm{NO}_{2}^{-}$and $\mathrm{NO}_{3}^{-}$. Also, organic and inorganic phosphorus is found and the following elements are detected: $\mathrm{Na}, \mathrm{K}, \mathrm{Ca}, \mathrm{Mg}, \mathrm{Fe}, \mathrm{Co}, \mathrm{Ni}$ and $\mathrm{Mn}$. High sodium content indicates that large quantities of alkaline cleaning chemicals are used [10].

The problems with pre-treatment of dairy processing wastewater arise not only from high values of pollution parameters but also from varying daily wastewater discharges, production profile, raw materials, technological level, cleaning and disinfection processes, quantity of water used and high exploitation costs [1,13]. Discharges of dairy wastewater and its concentration of pollutants differ over time [5]. They are affected by the production profile of the plant which is usually a sequence of periodic processes. An example of this is production of processed milk for consumption, which is a sequence of the following technological stages: milk collection, centrifugation, pasteurisation, normalisation of fat content in milk, cleaning and filling of containers and cleaning of machines and rooms after the process has been finished. Wastewater with varied $\mathrm{pH}$ levels and concentration of pollutants is produced at each of these stages.

\section{RESULTS AND DISCUSSION}

The most important dairy industry-related pollutants in wastewater are as follows: varying $\mathrm{pH}$, high $\mathrm{BOD}_{5}$, high fat content and high total suspended solids [3].

Raw (total) wastewater discharged by the Ciechanów Dairy Cooperative had high COD $\left(4,895 \mathrm{mg} \mathrm{O} / \mathrm{dm}^{3}\right.$, on average). It was much higher in the afternoon than in the morning. Raw wastewater sampled in discharges from fromage fraise and cottage cheese production lines had much higher COD (Table 1) which fell within the range reported by Chudzik [4].

COD values in typical wastewater discharged by dairy processing plants in Poland range from 1,800 to $9,000 \mathrm{mg} \mathrm{O}_{2} / \mathrm{dm}^{3}$ [4]. According to Struk-Sokołowska [16], a typical dairy process- 
ing plant discharges from 450 to $600 \mathrm{~m}^{3} / \mathrm{d}$ wastewater with an average COD value of $2,077 \mathrm{mg}$ $\mathrm{O}_{2} / \mathrm{dm}^{3}$. Other authors have reported COD values of $3,700 \mathrm{mg} \mathrm{O}_{2} / \mathrm{dm}^{3}$. The COD values obtained in the study reported here were much higher than the findings mentioned by Bartkiewicz [2]. The wastewater discharged by milk processing plants in Poland normally contains an average of 1,500 mg total suspended solids. The total wastewater discharged by the Ciechanów Dairy Cooperative had the concentration of total suspended soils which was twice as high in the afternoon $(1,100$ $\left.\mathrm{mg} / \mathrm{dm}^{3}\right)$. The quantity of total suspended solids in the wastewater analysed was quite high: 6,818 $\mathrm{mg} / \mathrm{dm}^{3}$ for the cottage cheese production line and $6,992 \mathrm{mg} / \mathrm{dm}^{3}$ for the fromage fraise production line. The solids were much lower than the values reported by Grala [9].

The highest pollution levels are determined in wastewater generated during cheese production as it contains $30 \mathrm{~g} / \mathrm{kg}$ solids [9]. Other authors $[6,8,15]$ claim that the total suspended solids in dairy wastewater may reach the level of 2,000 $\mathrm{mg} / \mathrm{dm}^{3}$. Fat content in the total wastewater sampled in the morning and in the evening was 130 and $1,300 \mathrm{mg} / \mathrm{dm}^{3}$, respectively. The values fell within the range reported by FAPA and others $[6$, $8,15]$. Fat content in normal wastewater generated by milk processing plants in Poland is 500 mg per one litre of milk processed [7]. Wastewater sampled from the fromage fraise production line discharges had a much higher concentration of fats than the total wastewater (Table 1). The orthophosphate content in dairy wastewater reported in Polish literature falls within the range of 11.9-45.9 $\mathrm{mg} \mathrm{PO}_{4}^{3-} / \mathrm{dm}^{3}[17]$. In the present work, the content was very low because organic phosphorus was the dominant form in the wastewater.
The average concentration of orthophosphates in the total wastewater was $1.13 \mathrm{mg} / \mathrm{dm}^{3}$, including $1.58 \mathrm{mg} \mathrm{PO}_{4}^{3-} / \mathrm{dm}^{3}$ for the cottage cheese production line and $0.35 \mathrm{mg} \mathrm{PO}{ }_{4}^{3-} / \mathrm{dm}^{3}$ for fromage fraise. The respective concentrations of total nitrogen were $1,258.6 \mathrm{mg} / \mathrm{dm}^{3}$ (which is a high value) and $325.4 \mathrm{mg} / \mathrm{dm}^{3}$ (Table 1). The average concentration of total nitrogen in raw wastewater was $96.5 \mathrm{mg} / \mathrm{dm}^{3}$ and was much lower than the values reported by Anielak [1].

$\mathrm{pH}$ values in dairy wastewater range from 4.5 to 9.2 [2]. The samples of raw wastewater taken in the morning and in the afternoon were alkaline whereas the $\mathrm{pH}$ for wastewater associated with both the production lines was very acidic and ranged from 4.8 to 5.1 (Table 1).

Total wastewater, including industrial sewage, domestic sewage and rainfall, generated by the Ciechanów Dairy Cooperative was transferred, using one sewer, to TOS10 device which is a sedimentary flotation separator of mud, oils and fats. The device produces average $\mathrm{COD}_{5}$ and $\mathrm{pH}$ values and removes solid particles, fats as well as oils. The permissible values of pollution indicators are set in the water legal permit which is issued by the Water and Sanitation Company in Ciechanów. The wastewater leaving the separator has to be characterised by certain pollution parameters. Only then can it enter the municipal sewers and the wastewater treatment facility in Ciechanów.

Table 2 presents minimum, average and maximum values of total wastewater pollution parameters following neutralisation as well as the standards set in the water legal permit.

The values of pollution parameters in wastewater pre-treated by means of neutralisation indicated that $\mathrm{BOD}_{5}$ was the lowest in winter $(230$

Table 1. Characteristics chemical physics stricte sewers - general and line of curd cheeses and homogenized cheeses

\begin{tabular}{|c|c|c|c|c|c|}
\hline \multirow{3}{*}{ Indicators of pollution } & \multirow{3}{*}{ Unit } & \multicolumn{4}{|c|}{ Stricte sewers } \\
\hline & & \multicolumn{2}{|c|}{ Sewers general } & \multirow{2}{*}{$\begin{array}{l}\text { Line of curd } \\
\text { cheeses } \\
8^{30}\end{array}$} & \multirow{2}{*}{\begin{tabular}{|c|}
$\begin{array}{c}\text { Line of homogenized } \\
\text { cheeses }\end{array}$ \\
$9^{00}$ \\
\end{tabular}} \\
\hline & & $7^{30}$ & $11^{30}$ & & \\
\hline $\mathrm{ChZT}^{*}$ & $\mathrm{mg} \mathrm{O}_{2} / \mathrm{dm}^{3}$ & 3900.0 & 5890.0 & 51200.0 & 68280.0 \\
\hline General suspensions & $\mathrm{mg} / \mathrm{dm}^{3}$ & 7000.0 & 1500.0 & 6818.0 & 6992.0 \\
\hline General nitrogen & $\mathrm{mg} \mathrm{N}_{\mathrm{og}} / \mathrm{dm}^{3}$ & 79.1 & 113.96 & 1258.6 & 325.4 \\
\hline Orthophosphates & $\mathrm{mg} \mathrm{PO}_{4}{ }^{3-} / \mathrm{dm}^{3}$ & 1.51 & 0.75 & 1.58 & 0.35 \\
\hline Reaction & $\mathrm{pH}$ & 8.07 & 8.27 & 5.1 & 4.8 \\
\hline Canailles & $\mathrm{mg} / \mathrm{dm}^{3}$ & 130.0 & 1500.0 & 3360.0 & 10844.0 \\
\hline
\end{tabular}

* ChZT - Chemical demand for oxygen. 
Table 2. Parameters of General sewers after the neutralization accompanied from the Ciechanów Dairy Cooperative for urban canalization

\begin{tabular}{|l|c|c|c|c|c|}
\hline \multicolumn{1}{|c|}{ Indicators of pollution } & Unit & Minimum value & Maximum value & Average value & $\begin{array}{c}\text { Norms of sewers } \\
\text { accompanied to } \\
\text { canalization }\end{array}$ \\
\hline BZT $_{5}{ }^{*}$ & $\mathrm{mg} \mathrm{O} / \mathrm{dm}^{3}$ & 230.0 & 2000.0 & 827.7 & 750.0 \\
\hline $\mathrm{ChZT}^{* *}$ & $\mathrm{mg} \mathrm{O} / \mathrm{dm}^{3}$ & 374.0 & 2874.0 & 1388.4 & 1200.0 \\
\hline $\mathrm{BZT}_{5} / \mathrm{ChZT}$ & - & 0.61 & 0.69 & 0.59 & - \\
\hline General suspensions & $\mathrm{mg} / \mathrm{dm}^{3}$ & 94.0 & 280.0 & 154.5 & 450.0 \\
\hline General nitrogen & $\mathrm{mg} \mathrm{N} / \mathrm{dm}^{3}$ & 13.0 & 75.0 & 40.0 & 100.0 \\
\hline General phosphorus & $\mathrm{mg} \mathrm{P} / \mathrm{dm}^{3}$ & 1.8 & 17.5 & 8.7 & 15.0 \\
\hline $\begin{array}{l}\text { Extracting substances } \\
\text { oneself with petroleum ether }\end{array}$ & $\mathrm{mg} / \mathrm{dm}^{3}$ & 6.0 & 66.0 & 27.8 & 100.0 \\
\hline Reaction & $\mathrm{pH}$ & 7.01 & 8.43 & 7.52 & $6.5-9.5$ \\
\hline
\end{tabular}

* BZT5 - Biochemical demand for oxygen.

** ChZT - Chemical demand for oxygen.

$\mathrm{mg} \mathrm{O} / \mathrm{dm}^{3}$ ), whereas COD fell within the range of 332 to $374 \mathrm{mg} \mathrm{O}_{2} / \mathrm{dm}^{3}$. Average permissible $\mathrm{BOD}_{5}$ and COD values were exceeded in March as they increased to 1,550 and $2,874 \mathrm{mg} \mathrm{O}_{2} / \mathrm{dm}^{3}$, respectively. In April and May, the respective ranges for $\mathrm{BOD}_{5}$ and COD were $580-660 \mathrm{mg} \mathrm{O}_{2} /$ $\mathrm{dm}^{3}$ and $998-1,112 \mathrm{mg} \mathrm{O}_{2} / \mathrm{dm}^{3}$. In late June and early July, the values of both parameters slightly exceeded the permissible averages; in August they were the highest $\left(2,000\right.$ and 2,720 $\mathrm{mg} \mathrm{O}_{2} /$ $\mathrm{dm}^{3}$, respectively) but dropped in September (to the level of 400 and $1,100 \mathrm{mgO} / \mathrm{dm}^{3}$, respectively). In December, both $\mathrm{BOD}_{5}$ and COD increased again and amounted to 1,000 and $1,450 \mathrm{mg} \mathrm{O}_{2} /$ $\mathrm{dm}^{3}$, respectively (Figure 1).

The lowest concentration of total suspended solids $\left(94 \mathrm{mg} / \mathrm{dm}^{3}\right)$ was obtained in February but in March it was the highest $\left(280 \mathrm{mg} / \mathrm{dm}^{3}\right)$. In April solids decreased and amounted to $95 \mathrm{mg} /$ $\mathrm{dm}^{3}$, in late June and early July they increased to the level of $197 \mathrm{mg} / \mathrm{dm}^{3}$. The increase contin- ued in August till the value of $276 \mathrm{mg} / \mathrm{dm}^{3}$ was reached (Figure 2).

Total nitrogen content of neutralised wastewater ranged from 13 to $75 \mathrm{mg} \mathrm{N} / \mathrm{dm}^{3}$, the lowest being in February and the highest in August. The values of pollution parameters for total suspended soils and total nitrogen demonstrated that wastewater entering the municipal sewage system met the standards set in the water legal permit (Figure 2).

The highest ether extract concentration was recorded in January and the lowest during late June-early July period (66 and $6 \mathrm{mg} / \mathrm{dm}^{3}$, respectively) (Figure 3 ). The lowest total phosphorus concentration $\left(1.8 \mathrm{mg} / \mathrm{dm}^{3}\right)$ was determined in January; it increased in March $\left(911.5 \mathrm{mg} / \mathrm{dm}^{3}\right)$ and was the highest in April $\left(17.5 \mathrm{mg} / \mathrm{dm}^{3}\right)$, which meant that the average permissible value for the parameter was slightly exceeded. After a decrease to the level of $10.6 \mathrm{mg} / \mathrm{dm}^{3}$ in May, total phosphorus increased again in August (14.6 mg/

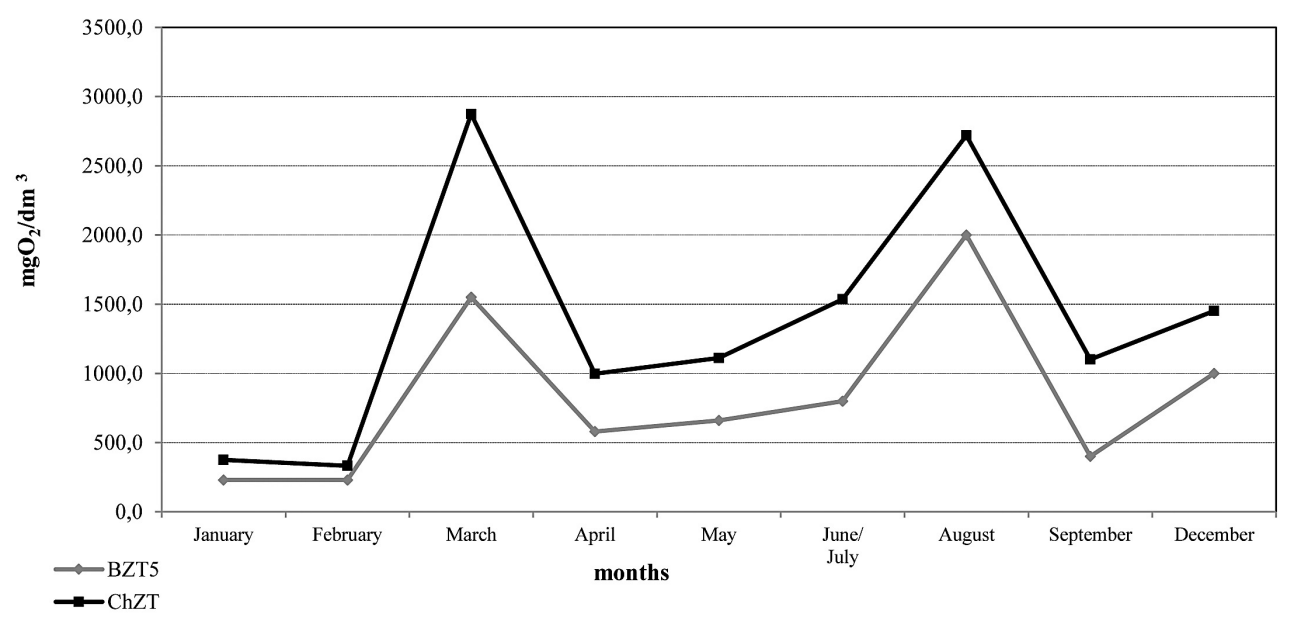

Figure 1. Characteristics physics-chemical of general sewers after neutralization (BZT5, ChZT) 


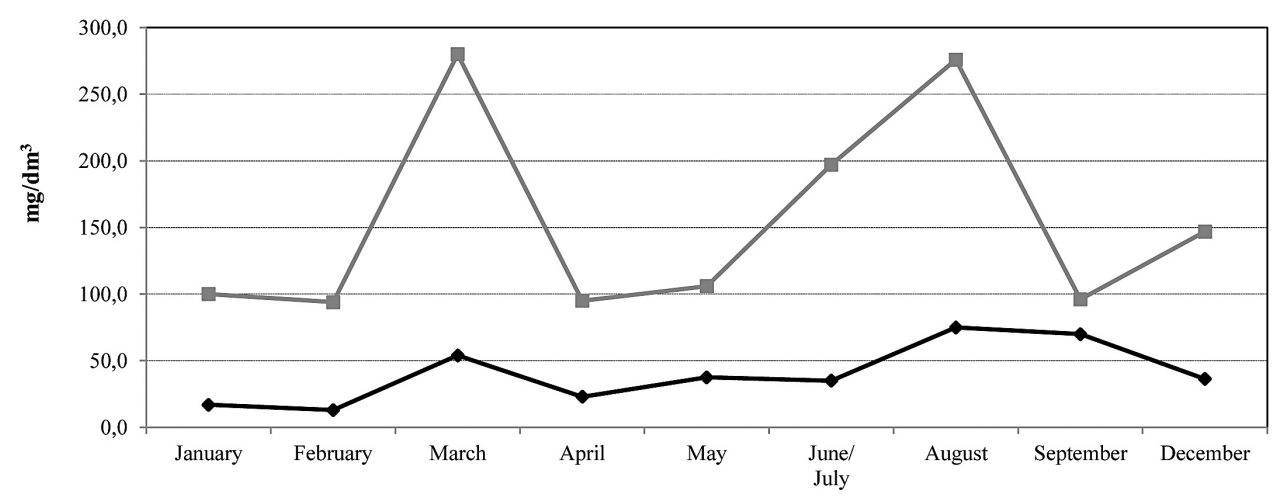

- - General suspensions

months

Figure 2. Characteristics physics-chemical of general sewers after neutralization

(General suspensions, General nitrogen)

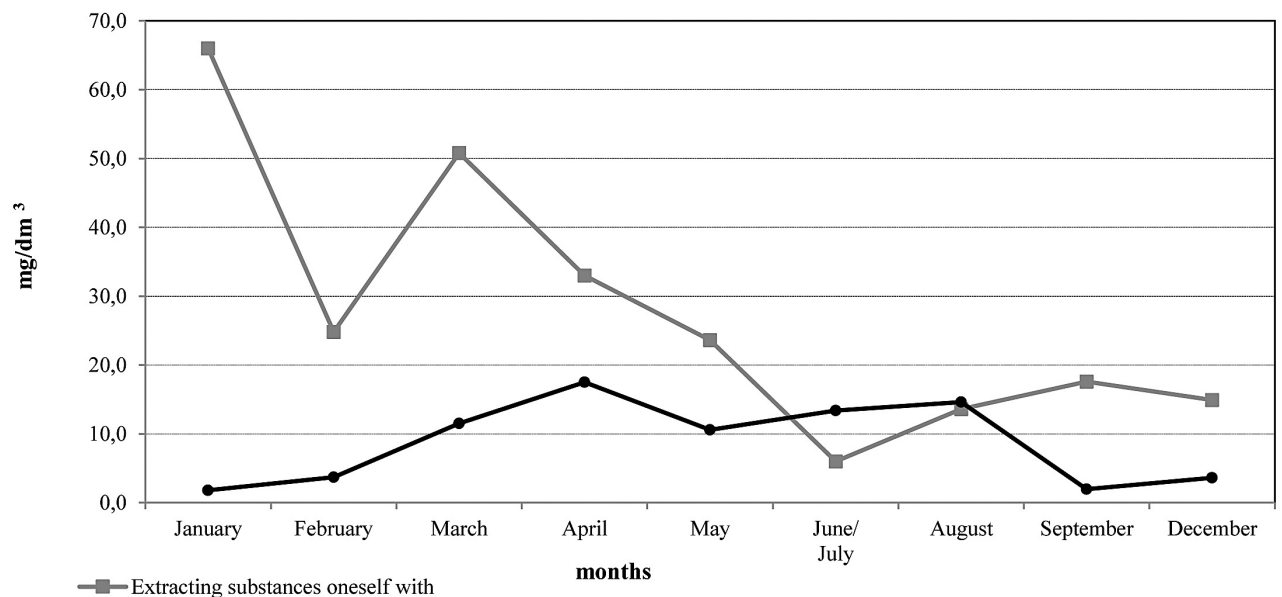

petroleum ether

Figure 3. Characteristics physics-chemical of general sewers after neutralization (Extracting substances oneself with petroleum ether, General phosphorus)

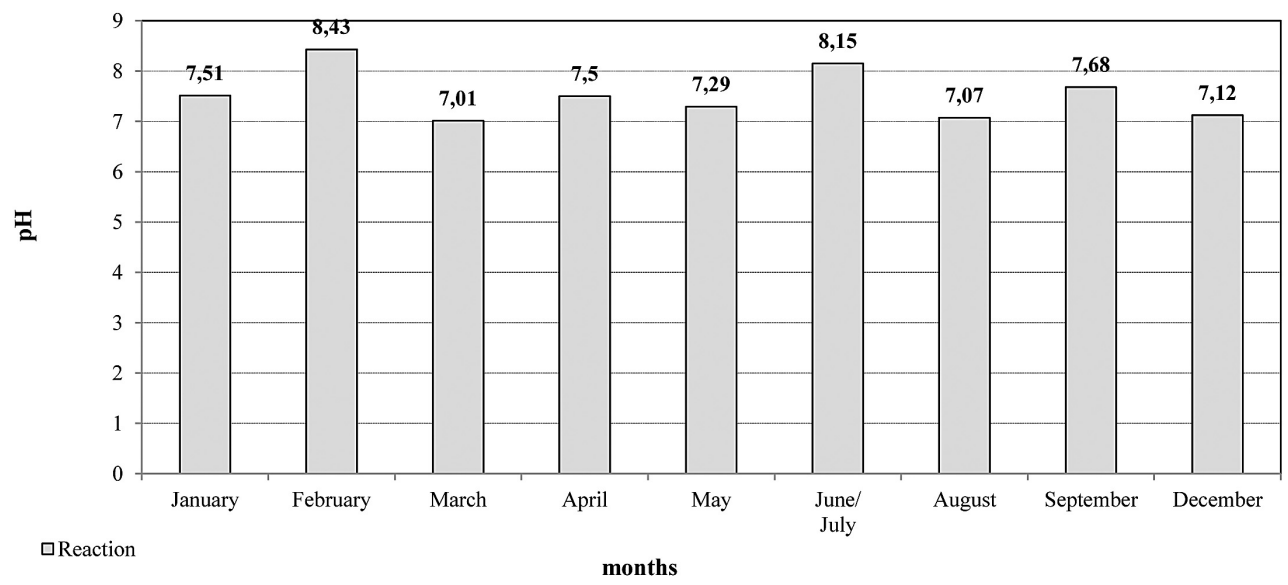

Figure 4. Characteristics physics-chemical of general sewers after neutralization (Reaction)

$\left.\mathrm{dm}^{3}\right)$ and then dropped in September (1.96 mg $\mathrm{P}_{\text {og }} / \mathrm{dm}^{3}$ ) (Figure 3).

Wastewater $\mathrm{pH}$ ranged from 7.01 to 8.15 , the lowest being in March and August (7.01 and 7.07, respectively) and the highest in February and during the late June-early July period. The $\mathrm{pH}$ values in the remaining months ranged from 7.29 to 7.68 (Figure 4). 


\section{CONCLUSIONS}

Both raw wastewater and sewage from the fromage fraise and cottage cheese lines entering the separator had high concentrations of pollutants. Despite this they fell within the range of typical values determined in dairy wastewater. Chemical neutralisation reduced COD, total solids and total nitrogen by $75.8,85$ and $58.5 \%$, respectively.

Dairy wastewater discharged by the Ciechanów Dairy Cooperative met most of the standards set for wastewater entering the municipal sewerage system. COD and $\mathrm{BOD}_{5}$ values for pretreated wastewater only periodically exceeded the permissible values set in the water legal permit. The remaining parameters remained below the acceptable levels.

\section{REFERENCES}

1. Anielak A.M. 2008. Gospodarka wodno-ściekowa przemysłu mleczarskiego. Agro Przemysł, 2, 57-59.

2. Bartkiewicz B., Umiejewska K. 2010. Oczyszczanie ścieków przemysłowych. PWN, Warszawa.

3. BAT - Best Available Techniques. 2005. Najlepsze dostępne techniki (BAT) wytyczne dla branży mleczarskiej, praca wykonana przez WS ATKINS - POLSKA Sp. z o. o. na zamówienie Ministerstwa Środowiska.

4. Chudzik B. 1997. Charakterystyka ścieków przemysłowych. Ekoinżynieria, 2, 19-21.

5. Danków R, Cais-Sokolińska D, Pikul J. 2009. Wykorzystanie popłuczyn mleczarskich w celu odzyskania masy białkowej. Nauka Przyroda Technol. 3(4), 116.

6. Dyatlova G., Pevnev S. and Fedorovskaya T. 2008. Treatment of milk plants wastewater. Water Supply and Sanitary Technique, 2, 12-15.

7. FAPA 1998, Ochrona środowiska w przemyśle mleczarskim. Publikacja sfinansowana ze środków Unii Europejskiej programu PHARE będących w dyspozycji Fundacji Programów Pomocy dla Rolnictwa (FAPA). Projekt P9312/04 - 02, Warszawa.

8. Gorban N. 2007. Purification facilities for the meat and dairy industries. Book of Abstracts Scientific and Practical Conference "Water \& Environment"
V International Water Forum "Aqua Ukraine 2007", 109-110.

9. Grala A, Zieliński M, Dudek M, Dębowski M. 2010. Efektywność oczyszczania ścieków mleczarskich w reaktorze beztlenowym o przepływie pionowym. Inżynieria Ekologiczna 22, 97-105.

10. Guillen-Jimenez E., Alvarez-Mateos P., RomeroGuzman F., Pereda-Martin J. 2000. Bio-mineralization of organic matter as affected by $\mathrm{pH}$. The evolution of ammonium and phosphates. Water Research, 34, 1215-1224.

11. Hermanowicz W., Dojlido J., 2010. Fizycznochemiczne badanie wody i ścieków, Arkady Publishing House.

12. Kajurek M., Dąbrowski W. 2003. Przeróbka i zagospodarowanie osadów ściekowych z oczyszczalni ścieków mleczarskich na przykładzie S.M. Mlekovita. II Międzynarodowa Konferencja Nowe Spojrzenie na osady ściekowe, odnawialne źródła energii, Częstochowa.

13. Krzemińska D., Neczaj E., Grosser A. 2011. Application of Advanced Oxidation Processes (AOP's) for the Industrial Wastewater Treatment. Acta Biochimica Polonica, IV Congress of Polish Biotechnology and IV EUROBIOTECH "Four Colours of Biotechnology" Central European Congress of Life Sciences, Vol. 58, Suppl. 4, Kraków.

14. Kushwaha J.P., Srivastava V.Ch., Mall I.D. 2011. An overview of various technologies for the treatment of dairy wastewaters. Critical Reviews in Food Science and Nutrition, 51, 442-452.

15. Sabliy L., Konontsev S. 2003. Wastewater treatment biotechnology for the plants of milk industry. Visnyk of UDUVGP, 2 (21), 142-150.

16. Struk-Sokołowska J. 2011. Wpływ ścieków mleczarskich na frakcje ChZT ścieków komunalnych. Inżynieria Ekologiczna, 24, 130-144.

17. Świerczyńska A., Bohdziewicz J., 2013. Współoczyszczanie odcieków ze ściekami mleczarskimi w sekwencyjnym bioreaktorze membranowym. Journal of Civil Engineering, Environment and Architecture, Vol. XXX, Issue 60 (3/13), 82.

18. Wierzbicki T.L., Dąbrowski W., Magrel L., 2005. Oczyszczanie ścieków, unieszkodliwianie i przeróbka osadów ściekowych pochodzących $\mathrm{z}$ zakładów przetwórstwa mleczarskiego. Research Project No 7 TO7G 029 11. Białystok University of Technology. 